\title{
PERSEPSI SOSIAL PRIA TRANSGENDER TERHADAP PEKERJA SEKS KOMERSIAL
}

\author{
Devi Eka Johana \\ Prodi Psikologi, Fakultas Pendidikan Psikologi, Universitas Negeri Malang \\ devijohana93@gmail.com \\ Fattah Hanurawan \\ Prodi Psikologi, Fakultas Pendidikan Psikologi, Universitas Negeri Malang \\ Indah Yasminum Suhanti \\ Prodi Psikologi, Fakultas Pendidikan Psikologi, Universitas Negeri Malang
}

\begin{abstract}
Abstrak
Penelitian ini bertujuan untuk mengungkap secara mendalam persepsi sosial transgender terhadap pekerja seks komersial. Metode penelitian yang digunakan adalah pendekatan kualitatif dan model penelitian studi kasus fenomenologi. Partisipan pada penelitian ini adalah tiga pria transgender yang berprofesi sebagai pekerja seks komersial. Pengumpulan data dilakukan dengan wawancara terpimpin, observasi dan catatan lapangan. Teknik analisis data menggunakan analisis tematik dan validasi data menggunakan triangulasi sumber dan member checking. Hasil penelitian menunjukkan bahwa persepsi sosial pria transgender terhadap pekerja seks komersial adalah seorang wanita yang bekerja memberi layanan seks komersial untuk tujuan pemenuhan ekonomi dan kebutuhan psikologis. Mereka tidak memiliki penampilan fisik menarik secara seksual namun memiliki interaksi sosial dan konsep diri yang baik.
\end{abstract}

Kata Kunci: persepsi sosial, pria transgender, pekerja seks komersial

Manusia merupakan makhluk sosial. Setiap manusia membutuhkan hubungan dengan orang lain untuk kelangsungan hidupnya. Hubungan dengan orang lain ini tidak terlepas dari peran lingkungan sosial dalam membentuk persepsi. Persepsi merupakan serangkaian proses pembentukan perilaku, pikiran, perasaan yang dimaknai oleh indera terhadap orang lain disebut persepsi sosial. Persepsi sosial, dalam arti mengenali dan mengerti orang lain, merupakan aktivitas yang sangat unik dikarenakan setiap manusia mempunyai ciri khas dan karakteristik yang berbeda. Perbedaan karakteristik pada manusia menimbulkan persepsi yang berbeda juga pada setiap orang. Hal ini dikarenakan proses persepsi yang direspon oleh alat indera pada setiap orang yang berbeda. Setiap orang mempunyai cara yang berbeda dalam mengenali dan memahami karakter satu sama lain. Dalam hal ini, persepsi sosial merupakan hal yang sangat penting untuk memahami orang lain. Pemahaman tentang orang lain tersebut membantu terjadinya interaksi yang baik. Jika interaksi yang baik sudah terjadi maka harapan untuk pemenuhan kebutuhan dan hidup yang lebih baik akan terlaksana.

Persepsi individu terhadap orang lain tidak terlepas dari pengaruh lingkungan. Lingkungan memberi pengaruh pada perkembangan individu melalui penanaman nilai-nilai, norma-norma, maupun aturan-aturan yang dianut dalam masyarakat (Jasruddin \& Daud, 2016). Adat yang berlaku dalam masyarakat merupakan salah satu wujud norma yang di dalamnya terdapat batasan-batasan dan hanya dapat dipahami maksudnya oleh sekelompok orang yang menjalankannya secara turun temurun. Salah satu batasan yang dianggap menyimpang menurut masyarakat adalah peran pria transgender(laki-laki yang mempunyai kepribadian seperti perempuan atau disebut wanita pria). 
Dalam pandangan masyarakat, lahirnya perilaku pria transgender tidaklepas dari suatu proses atau dorongan yang kuat dari dalam dirinya, bahwa fisik mereka tidak sesuai dengan kondisi psikis, hal ini menimbulkan konflik psikologis dalam dirinya (Jasruddin \& Daud, 2016). Pria transgender lekat dengan citranya sebagai pekerja seks komersial, meskipun tidak semuanya, namun label tersebut selalu menyertai pria transgender. Pilihan hidup menjadi transgender bukanlah hal mudah. Proses pencarian identitas gender di tengah masyarakat yang heteroseksual membuat pria transgender merasa kesulitan untuk melakukan adaptasi. Identitas diri merupakan aspek penting dalam perkembangan manusia, tidak terkecuali pada pria transgender. Dalam pencarian identitas diri, pria transgender mengalami beberapa konflik dalam diri mereka yang dimulai dari masa anak-anak.

Pencarian identitas diri dimulai pada anak-anak melalui observasi dan peniruan perilaku gender, dan melalui mekanisme hadiah serta hukuman anak-anak mengalami perilaku gender yang sesuai dan tidak sesuai (Santrock, 2002). Beberapa hal yang mempengaruhi proses ini adalah pengaruh pengasuhan, pengaruh teman sebaya, pengaruh sekolah dan guru, serta pengaruh media. Dalam hal ini pria transgender berada dalam keadaan dilema antara konflik dalam diri mereka yang belum menemukan penyelesaian dengan penyesuaian diri pada norma kelompok dalam masyarakat yang wajib untuk dipatuhi. Perhatian dan perilaku individu dipandu oleh motivasi internal untuk menyesuaikan diri dengan standar dan stereotipstereotip sosial budaya yang berbasis gender (Santrock, 2002). Masyarakat belum sepenuhnya menerima dan mengakui keberadaan mereka. Norma masyarakat yang masih menganggap tabu akan hal keberadaan transgender yang dianggap menyimpang sehingga terkesan menolak keberadaan pria transgender sampai melupakan hak kaum transgender sebagai sesama manusia.

Munculnya perilaku yang dianggap menyimpang oleh masyarakat, yaitu perilaku priatransgender seperti yang dipaparkan sebelumnya, dimulai dari adanya gangguan identitas gender. Menurut Carroll (dalam Nevid dkk., 2005), individu dengan gangguan identitas gender umumnya sudah mulai merasakan indikasi gangguan tersebut sejak kecil, dimana ia merasa bahwa dirinya adalah jenis kelamin yang berbeda dengan jenis kelaminnya saat ini, dan perasaan ini terus berlanjut hingga masa dewasa. Keputusan untuk menjadi pria transgender melalui proses yang panjang. Meskipun pria transgender menyadari perubahan ini di kemudian hari akan banyak mendatangkan masalah, seperti kebingungan dengan identitas, tidak diterimanya mereka dalam lingkungan masyarakat karena pertentangan konstruksi gender (Putri \& Sutarmanto, 2009).

Menurut UNAIDS/JC2656, yaitu penelitian tentang AIDS dari PBB tahun 2014 ada beberapa permasalahan yang membuat transgender merasa semakin terpinggirkan, yaitu : (1) penolakan oleh pihak keluarga, (2) pelanggaran Hak Asasi Manusia untuk memperoleh pendidikan dan pekerjaan, (3) kekerasan, perilaku criminal, dan transfobia, (kekurangan pengakuan terhadap identitas gender, (5) diskriminasi dalam sistem pelayanan kesehatan.

Masalah yang dialami oleh pria transgender meliputi hampir seluruh aspek kehidupan sosial, seperti perolehan kesempatan pendidikan, kesempatan kegiatan keagamaan, kesempatan terlibat dalam kegiatan di masyarakat, kesempatan mendapat perlindungan hukum dan hambatan dalam memperoleh pekerjaan. Hal tersebut menimbulkan hubungan kurang harmonis antara pria transgender dengan lingkungan sosialnya. Kondisi tersebut juga menyebabkan pria transgender kesulitan mendapatkan pekerjaan yang lebih baik dalam mengakses sumber-sumber yang ada, masih rendahnya pendapatan yang mereka dapatkan menyebabkan belum terpenuhinya kebutuhan dasar yang baik. Akhirnya beberapa dari mereka memilih untuk mennggunakan seks sebagai pemenuhan kebutuhan ekonomi.

Ada beberapa alasan pria transgender ini menjadi pekerja seks komersial, salah satunya faktor ekonomi (untuk mencukupi kebutuhan pria transgender itu sendiri, kebanyakan sebagai penopang keluarga/orang-orang yang menjadi tanggungannya, alasan lain adalah untuk 
mencukupi kebutuhan biologis. Fakta menunjukkan bahwa sebagian besar pria transgender memilih bekerja sebagai pekerja seks komersial (Mustikawati dkk., 2013). Profesi sebagai pekerja seks komersial inilah yang menjadi labelyang melekat pada pria transgender dan menimbulkan stigma di masyarakat. Kekerasan perlakuan dari aparat (Satpol PP) juga sering dialami oleh mereka. Selain itu, sering juga terjadi pemerasan oleh aparat berupa pemalakan uang hasil "kerja" para transgender pekerja seks komersial tersebut. Dalam lapangan pekerjaan, mereka seringkali mengalami perlakuan "diskriminatif". Sebagian besar masyarakat tidak mau mempercayakan pekerjaan diberikan kepada pria transgender. Penolakan masyarakat ini jelas menimbulkan masalah sosial bagi komunitas pria transgender, termasuk dalam memperoleh pekerjaan (Mustikawati dkk., 2013).

Faktor yang mendorong pria transgender untuk lebih memilih bekerja dan terjun dalam bidang pelacuran tidak hanya dari masalah ekonomi saja melainkan lebih untuk pemenuhan kepuasan batin. Dalam menjalankan pekerjaan sebagai pekerja seks komersial, adanya faktor tersebut juga dapat menyebabkan timbulnya beberapa masalah. Salah satu masalah yang muncul yaitu adanya persepsi masyarakat terhadap identitas gender pada kaum pria transgender dan timbulnya persepsi antar pekerja seks komersial. Beberapa kasus ditemukan konflik antara pria transgender yang menjadi pekerja seks komersial dan pekerja seks komersial wanita. Lingkungan sekitar tempat pria transgender bekerja sebagai pekerja seks komersial di lokalisasi juga dapat menimbulkan persepsi sosial. Pria transgender menganggap pekerja seks komersial wanita telah merebut pasar mereka, membuat mereka terancam dan menghambat pekerjaan mereka. Sebagian besar dari pria transgender sampai rela mempermak tubuhnya seperti operasi plastik, suntik untuk kulit lebih putih, perawatan tubuh secara rutin, sulam alis, sampai suntik silikon untuk menambah ukuran payudara. Semua yang dilakukan bertujuan untuk menarik perhatian dan memuaskan pelanggan. Dalam beberapa waktu diperoleh pernyataan dari beberapa pria transgender yang juga memasang susuk kecantikan untuk menyaingi pekerja seks komersial wanita.

Keadaan diatas memperlihatkan adanya konflik antara pria transgender yang menjadi PSK dan PSK wanita. Konflik tersebut dapat diselesaikan diawali dengan melihat bagaimana persepsi sosial pria trangender terhadap PSK wanita. Oleh karena itu penelitian ini bertujuan untuk mengetahui dan mengungkap secara mendalam persepsi sosial pria transgender terhadap pekerja seks komersial.

\section{PERSEPSI SOSIAL}

Pengertian persepsi menurut Shiraev \& Levy (2012) merupakan proses yang mengorganisasikan berbagai sensasi menjadi pola yang bermakna. Menurut Matsumoto (2008) persepsi adalah tindakan menyusun informasi dari organ-organ sensorik menjadi suatu keseluruhan yang bisa kita pahami. Apabila yang dipersepsikan keberadaan orang lain sebagai objek persepsi disebut dengan persepsi sosial (Yoviy, 2012). Adapun pengertian persepsi sosial menurut Baron \& Byrne (2004) suatu proses lebih tepatnya proses-proses yang digunakan untuk mencoba memahami orang lain. Penjelasan lain dilengkapi oleh Robbins (dalam Hanurawan, 2010) bahwa persepsi sosial adalah adalah proses dalam diri seseorang yang menunjukkan organisasi dan interpretasi terhadap kesan-kesan inderawi, dalam usaha untuk memberi makna terhadap orang lain sebagai objek persepsi.Persepsisosial adalah proses menilai dan membentuk kesan tentang karakteristik orang lain (Watson dkk., 1984).Dari beberapa definisi tersebut, persepsi sosial dapat diartikan sebagai proses perolehan, penafsiran, pemilihan, dan pengaturan informasi inderawi tentang orang lain. Apa yang diperoleh, ditafsirkan, dipilih, dan diatur adalah informasi inderawi dari lingkungan sosial serta yang menjadi fokusnya adalah orang lain (Sarwono \& Meinarno, 2015).

\section{PRIA TRANSGENDER}

\section{Pengertian}

transgendermenurutRosenthal (2013) adalah istilah umum yang digunakan untuk mengekspresikan variasi gender, termasuk 
peniruan sebagai laki-laki atau perempuan. Selain itu, transgender juga dapat didefinisikan sebagai pelanggaran peran gender dan identitas gender dan/atau melintasi batas-batas gender lainnya (Green dalam Nagoshi \& Brzuzy, 2012). Ciri khas transgendermengungkapkan identitas luar gender berdasar definisi heteronormatif tradisional, tetapi mungkin memiliki niat sedikit atau tidak melakukan operasi kelamin kembali atau perawatan hormon (Bornstein dalam Nagoshi \& Brzuzy, 2012).

Pengertian Pekerja seks komersial diartikan sebagai kurang beradab karena keroyalan relasi seksualnya dalam bentuk penyerahan diri pada banyak laki-laki untuk pemuasan seksual dan mendapatkan imbalan jasa atau uang bagi pelayanannya. Pekerja seks komersial merupakan peristiwa penjualan diri dengan jalan menjualbelikan badan, kehormatan dan kepribadian kepada banyak orang untuk memuaskan nafsu-nafsu seks dengan imbalan pembayaran (Kartono, 2011).

Pria transgender dan pekerja seks komersial wanita sering terjadi konflik dalam satu agen lokalisasi. Keberadaan wanita dalam satu agen lokalisasi dianggap mengganggu pelanggan pria transgender. Permasalahan tersebut perlu untuk peneliti dalami terkait pria transgender dalam mempersepsikan pekerja seks komersial wanita dalam satu lokalisasi.

\section{METODE}

Penelitian ini menggunakan pendekatan kualitatif, menurut Creswell (2009) merupakan metode -metode untuk mengeksplorasi dan memahami makna yang-oleh sejumlah individu atau sekelompok orang-dianggap berasal dari masalah sosial atau kemanusiaan. Proses penelitian kualitatif ini melibatkan upaya-upaya penting, seperti mengajukan pertanyaan-pertanyaan dan prosedur-prosedur, mengumpulkan data yang spesifik dari para partisipan, menganalisis data secara induktif mulai dari tema-tema yang khusus ke tema-tema umum, dan menafsirkan makna data.Rancangan atau model penelitian ini menggunakan studi kasus fenomenologi. Tujuan penggabungan itu adalah melakukan deskripsi suatu kasus yang memiliki hubungan dengan esensi pengalaman seseorang terkait suatu fenomena (Bursztyn dalam Hanurawan, 2012).Peneliti bertindak sebagai instrumen sekaligus pengumpul data. Instrumen selain manusia dapat pula digunakan, tetapi fungsinya terbatas sebagai pendukung tugas peneliti sebagai instrumen.

Lokasi penelitian ini bertempat di Kelurahan Dinoyo Kecamatan Lowokwaru Kota Malang. Pemilihan lokasi ini didasarkan pada lokasi ini memiliki tempat tersendiri untuk dijadikan tempat untuk mencurahkan isi hati terkait permasalahan yang dialami oleh pria transgender dan tempat untuk berkonsultasi terkait profesinya sebagai pekerja seks komersial. Sumber data utama dalam penelitian ini adalah partisipan yang mengetahui dan memiliki informasi pokok yang diperlukan dalam penelitian. Partisipan dalam penelitian ini yaitu priatransgender yang melakukan pekerjaan di lokalisasi Pekerja Seks Komersial. Jumlah partisipan penelitian terdapat 3 orang pria transgender dengan karakteristik yaitu memiliki alat kelamin lakilaki, bekerja sebagai pekerja seks komersial dan berusia antara puluh tahun sampai empat puluh tahun.

Dalam melakukan penelitian, alat pengumpul data yang sudah ada pada metode kualitatif adalah wawancara kualitatif, observasi kualitatif, dan studi dokumentasi.Teknik analisis yang digunakan adalah teknik analisis tematik. Teknik analisis tematik adalah analisis makna berdasarkan tema-tema yang menonjol yang berhubungan dengan kategori-kategori yang ada dalam tujuan penelitian (Hanurawan, 2012).Berdasarkan Hanurawan (2012) penemuan validitas dalam penelitian studi kasus fenomenologi terhadap suatu partisipan atau kelompok partisipan dilakukan melalui cek partisipan atau cek anggota partisipan. Dalam hal ini partisipan melakukan penelaahan terhadap kesimpulan hasil sebagai hasil interpretasi terhadap pengalaman fenomenologi partisipan.

\section{HASIL DAN PEMBAHASAN}

Dalam penelitian ini didapatkan hasil data persepsi sosial pria transgender yang dapat dibahas berdasarkan tiga dimensi, yang pertama Dimensi Fisik menjelaskan persepsi partisipan dalam melihat bentuk tubuh pekerja seks komersial. Partisipan terdiri dari tiga orang pria 
transgender yang berprofesi sebagai pekerja seks komersial, yaitu WH, RY, dan DA. WH melihat bentuk tubuh pekerja seks komersial wanita kurang menarik, perut kurang rata dan kurang baik. RY melihat bentuk tubuh pekerja seks komersial juga menjijikkan karena trauma masa lalu dengan wanita yang telah mengkhianatinya, dan tentang penggunaan pakaian yang kurang menarik mata. Sedangkan DA melihat bentuk tubuh pekerja seks komersial cenderung kurang terawat. Penilaian yang diberikan oleh ketiga partisipan tersebut, sesuai dengan yang diungkapkan oleh Newcomb dkk., (1978) bahwa persepsi sosial adalah mengenai sejumlah proses-proses yang tampil antara penyajian informasi tentang seseorang dan kesadaran orang itu.

Dimensi yang kedua yaitu dimensi sosial yang akan menjelaskan persepsi partisipan dalam melihat hubungan sosial pekerja seks komersial wanita dengan pekerja seks komersial lainnya. WH memberikan pendapat bahwa interaksi sosial yang terjadi antar pekerja seks sebagian besar pernah terjadi konflik, tergantung karakter tiap pekerja seks. RY juga mempunyai pendapat yang hampir sama yaitu interaksi sosial yang terjadi antar pekerja seks adakalanya muncul rasa saling iri. Sedangkan DA juga menambahkan interaksi sosial antar pekerja seks komersial terkait masalah tamu atau pelanggan, fokusnya adalah demi mendapatkan uang. Ketiga pernyataan partisipan tersebut sesuai dengan yang dikemukakan oleh Baron \& Byrne (2004) bahwa perilaku individu terhadap lingkungan sosialnya dapat diwujudkan dalam proses interaksi antar individu.

Dimensi yang ditemukan ketiga yaitu dimensi konsep diri yang akan menjelaskan persepsi partisipan dalam memahami alasan wanita memilih bekerja sebagai pekerja seks komersial dan syarat tampil percaya diri. Ketiga partisipan memberikan pendapat yang hampir sama, yaitu faktor ekonomi karena tuntutan gaya hidup yang konsumtif dan ingin hidup serba kecukupan. Faktor lain yang ikut berpengaruh adalah keluarga yang berpisah, merasa terjerumus dendam dinodai oleh kekasihnya dan faktor profesi menjadi pekerja seks adalah yang paling praktis tanpa menggunakan ijazah untuk menghasilkan uang. Hal tersebut sesuai dengan yang dikemukakan oleh Stephan (dalam Hanurawan,2010) sebagai upaya memahami keseluruhan gambaran komprehensif tentang diri orang lain, dalam proses pembentukan persepsi, seseorang mendayagunakan segenap informasi yang dimiliki untuk membentuk kesan-kesan tentang orang lain.

\section{KESIMPULAN DAN SARAN}

Persepsi sosial pria transgender terhadap pekerja seks komersial secara umum adalah seorang wanita yang bekerja memberi layanan seks komersial yang berpenampilan fisik kurang menarik secara seksual namun memiliki interaksi sosial dan konsep diri yang baik. Persepsi sosial pria transgender terhadap pekerja seks komersial juga dapat ditinjau melalui dimensi-dimensi persepsi sosial. Dimensi fisik yaitu persepsi sosial pria transgender terhadap penampilan fisik pekerja seks komersial wanita adalah kurang menarik secara seksual yang diindikasikan dengan bentuk tubuh yang kurang proporsional dan kurangnya kesadaran menjaga bentuk tubuh ideal. Dimensi sosial yaitu persepsi sosial pria transgender terhadap interaksi sosial pekerja seks komersial wanita adalah baik yang diindikasikan melalui keterampilan berkomunikasi dan pemecahan konflik. Dimensi konsep diri yaitu persepsi sosial pria transgender terhadap konsep diri pekerja seks komersial wanita adalah baik yang diindikasikan dengan kepercayaan diri dan penerimaan diri secara positif.

Saran yang dapat diberikan mengarah pada penelitian yang akan dilanjutkan selanjutnya. Penelitian yang sama dapat dilakukan dengan lebih banyak partisipan dan lebih mendalam. Juga penelitian tentang persepsi PSK wanita pada PSK transgender. Hal ini dapat memperkuat data untuk mencari penyelesaian konflik antara mereka.

Selain itu, berdasarkan data - data yang terkumpul baik persepsi maupun data tambahan yang lain, saran a yang dapat diberikan adalah perlu adanya intervensi sosial yang dilakukan oleh pemerintah dan masyarakat terkait penyelesaian konflik antara PSK transgender dan PSK wanita. Intervensi sosial tersebut 
ditujukan untuk (1) memberikan alternatif lain cara pemenuhan kebutuhan ekonomi untuk PSK transgender dan PSK wanita. Alternatif lain yang tidak menggunakan seks dan ijazah. (2) memberikan bantuan untuk menyelesaikan masalah - masalah psikologis yang merupakan salah satu penyebab penting munculnya PSK transgender dan PSK wanita.

\section{DAFTAR RUJUKAN}

Baron, Robert A. \& Byrne, Donn. 2004. Psikologi Sosial. Jakarta: Penerbit Erlangga.

Creswell, John W. 2009. Research Design : Pendekatan Kualitatif, Kuantitatif, dan Mixed. Yogyakarta: Pustaka Belajar.

Hanurawan, Fattah. 2010. Psikologi Sosial : Suatu Pengantar. Bandung: PT Remaja Rosdakarya.

Hanurawan, Fattah. 2012. Metode Penelitian Kualitatif Dalam Ilmu Psikologi. Surabaya: Pusat Studi Peningkatan Kinerja Masyarakat LPPM Universitas Airlangga Kampus C.

Jasruddin \& Daud, Jasmin. 2016. Transgender Dalam Persepsi Masyarakat. Jurnal Equilibrium. (online), v.2 No.1, hal. 1, diakses pada 11 Februari 2016.

Kartono, Kartini. 2011. Patologi Sosial. Jakarta: Rajawali Press.

Matsumoto, David. 2008. Pengantar Psikologi Lintas Budaya. Yogyakarta: Pustaka Belajar.

Mustikawati, Indah Rr., Nugroho, Mahendra A. Widiarti, Pratiwi W., 2013. Strategi Pemberdayaan Ekonomi Komunitas Waria melalaui Life Skill Education. (online), hal.1-4, diakses pada 22 September 2015.

Nagoshi, Julie L. \& Brzuzy, Stephan/ie. 2012. Transgender Theory:Embodying Research and Practice : Affilia
Journal of Women and Social Work. (online), p.431-443, diakses pada 27 September 2015.

Nevid, J.S., Rathus, S.A., \& Greene, Beverly., 2005. Psikologi Abnormal: Jilid 2. Jakarta: Penerbit Erlangga.

Putri, T.M. \& Sutarmanto, H. 2009. Kesejahteraan Subjektif Waria Pekerja Seks Komersial. Jurnal Psikohumanika, 2 (2), 46-55.

Rosenthal, Martha S., 2013. Human Sexuality From Cells to Society. USA:Wadsworth, Cengange Learning.

Santrock, J.W., 2002. Life-Span Development Perkembangan Masa Hidup. Edisi kelima. Jakarta: Penerbit Erlangga.

Sarwono, Sarlito W. \& Meinarno, Eko A.(Ed.). 2015. Psikologi Sosial. Jakarta: Salemba Humanika (Tim Penulis Fakultas Psikologi Universitas Indonesia).

Shiraev, Eric B.\& Levy, David A. 2012. Psikologi Lintas Kultural Pemikiran Kritis dan Terapan Modern. Jakarta: Penerbit Kencana.

UNAIDS (United Nations Programme on HIV/AIDS). 2014. Transgender People. The GAP report 2014. (online), p.3. 20 Avenue Appia CH1211 Geneva 27: Switzerland. Diakses pada 6 Oktober 2015.

Watson, David L., Tregerthan, G.deBortali, \& Frank, Joice. 1984. Social Psychology Science and Application. USA: Scott, Foresman and Company.

Yoviy. 2012. Pengertian Persepsi Sosial,(online), (http://educationaticlesjournal.blogs pot.co.id/2012/03/pengertianpersepsi-sosial.html), diakses pada $11 \quad$ Februari 2016 